Pak. j. sci. ind. res. Ser. A: phys. sci. 2020 63A(2) 130-138

\title{
Seasonal Assessment of Water Quality by Statistical Analysis in the Coastal Area of Sindh, Pakistan
}

\author{
Muhammad Imran Nasir*, Haq Nawaz Abbasi, Arif Zubair, Waqar Ahmad \\ Department of Environmental Science, Federal Urdu University of Arts, \\ Science and Technology Gulshan-e-Iqbal, Karachi, Pakistan \\ (received October 31, 2019; revised February 26, 2020; accepted March 3, 2020)
}

\begin{abstract}
Monitoring of groundwater is very important because of climatic and demographic patterns along the coastline of Sindh Province, Pakistan. Seventy representative groundwater samples were collected during pre-monsoon and post-monsoon seasons for the investigation of physico-chemical variables to understand the groundwater chemistry of the coastal belt. Multivariate statistical techniques were applied to interpret the data to reveal the pollution sources in the groundwater samples. The normalized charge balance index (NCBI) was computed on the data set and the $\Sigma \mathrm{Tz}^{-}$and $\Sigma \mathrm{Tz}^{+}$were analyzed in the collected groundwater samples. Cations were in excess and alkalinity in the aquifer of the study area was balanced by $\mathrm{Ca}^{+}+\mathrm{Mg}^{+}$ions. The contribution of ions was insignificant for charge balance. $\mathrm{Mg}^{+2}$ and $\mathrm{Ca}^{+2}$ were in huge concentration and alkaline hardness was maintained by the alkaline rocks formation. Majority of the charge was balanced by $\mathrm{SO}_{4}^{-2}$ and $\mathrm{Cl}^{-}$. In groundwater ionic composition is used to categorize it into ionic types of groundwater based on the dissolved cation and anion. The ionic reaction is likely regulated by domestic geological formation. The sample location illustrates $\mathrm{Na}^{+}-\mathrm{SO}_{4}^{-2}$ and $\mathrm{Na}^{+}-\mathrm{Cl}^{-}$nature of groundwater. The groundwater with $\mathrm{Na}^{+}-\mathrm{SO}_{4}{ }^{-2}$ and $\mathrm{Na}^{+}-\mathrm{Cl}^{-}$dominancy generally shows saline characteristics that make groundwater unfit to use for irrigation and drinking purposes.
\end{abstract}

Keywords: salinity, groundwater, NCBI, multivariate

\section{Introduction}

The only significant level of urbanization along the Pakistan coast is found in Karachi city, with a population of about 16 million (Qureshi et al., 2010). Around 17\% of the industries of the country is situated in Karachi, which includes textile, chemical, pharmaceutical, electronic, tanneries, oil refineries, food, iron and steel, etc. (Zeb et al., 2017). Whereas, district Thatta was previously considered as the most important agriculture centre along the coast of Pakistan (Alamgir et al., 2016). However, since the district is positioned at the tail end of the irrigation systems and there is a perpetual shortage of freshwater, agriculture has deteriorated.

Monitoring of groundwater on the coastal belt of Sindh Province, Pakistan is very important because of its climatic pattern and demographic pressure in this region (Qureshi, 2010). A large population of the area consumes groundwater for different uses (Yu et al., 2013), and over-exploitation causes deterioration in groundwater quality (Khuhawar et al., 2018; Bashir et al., 2017; Daud et al., 2017; Memon et al., 2011; Qureshi et al., 2008; Mastoi et al., 2008). On the other hand, the composition of groundwater modified as it added different

*Author for correspondence; E-mail: imrannasirc@gmail.com soluble material along its flow path and the behaviour and deviations leading to anomalous of specific elements in the groundwater. The configuration of groundwater differs at the lowest point of a constant stream. The variation of $\mathrm{pH}$, soil and rock constitutes, the resident time of groundwater inside the formation and landscape and seawater intrusion is also a significant factor in groundwater of coastal area. The overall outcome is that groundwater geochemistry is regulated in response to its flow path (Malott et al., 2016).

The study was conducted in the coastal belt of Province Sindh, Pakistan (Fig. 1). The coastal belt of Sindh covered total area of about $140,915 \mathrm{~km}^{2}$, while, sampling area was positioned between $24^{\circ} 4^{\prime}-28^{\circ} 7^{\prime} \mathrm{N}$ and $66^{\circ} 8^{\prime}-71^{\circ}$ E. The Province Sindh comprises arid and hottest climate with an average annual rainfall less than $200 \mathrm{~mm}$, whereas, summer and winter average temperature reaches above 40 and $16{ }^{\circ} \mathrm{C}$, respectively (Rasul et al., 2012). High evaporation, low precipitation, and canal irrigation network is the main characteristic of the study area (Steenbergen et al., 2015).

The Indus belt predominantly consists of alluvium, along with middle to upper tertiary rocks having lithology of sand, shale, and limestone. Nari formation in 
Oligocene age showing in the area having interlaying of limestone, shale, and siltstone. Gaj formation of Miocene age overlies Nari formation, having shale and sandstone with subordinate limestone. The conglomerate of Manchar formation Quaternary in age covers Gaj formation (Malkani, 2010). Mangho Pir, Dirgh Road/ PECHS, Landhi, and Korangi anticline marks the structural features of the area controls the water discharge from the effluent and seasonal rivers (Malir and Lyari) into the Arabian sea. Groundwater structure can be originated in fine channels through the river having the meander belt and streambed deposits. River Indus is the main source of irrigation network and aquifer recharge.

The Multivariate analysis methods of groundwater samples have been successfully used for chemical evaluation and data can be easily interpreted. In the current study, groundwater chemistry was evaluated using statistical applications. The study area is vulnerable to groundwater contamination which would ultimately risk the utilization of groundwater for different uses. There have been several studies on groundwater quality in the study area and had a focus on basic evaluation (Rubab et al., 2014; Husain et al., 2012; Zubair et al., 2010). The aim of the present study was to assess the groundwater quality in coastal areas of Sindh by using statistical analysis. The current study will be helpful for the identification of hydrogeochemical processes and characteristics controlling the chemistry of groundwater. Moreover, the results may help a clear understanding of adverse effects, and the solution. Concerning groundwater quality in the study area. This study is useful to determine the environmental impact of industrialization and urbanization on the coastal belt.

\section{Material and Methods}

A total of seventy representative groundwater samples were collected during each pre-monsoon and postmonsoon seasons to monitor the contamination and tried to identify the source, behaviour, distribution and transport pattern of contaminants along the coastal belt of Sindh Province, Pakistan. The variability in the groundwater composition is associated with the groundwater table that fluctuates during pre and postmonsoon seasons. Each of the groundwater samples was obtained during the month of March (pre-monsoon) and September (post-monsoon), respectively. The fresh bottles were washed with distilled water and then rinsed twice with groundwater being sampled before filling.

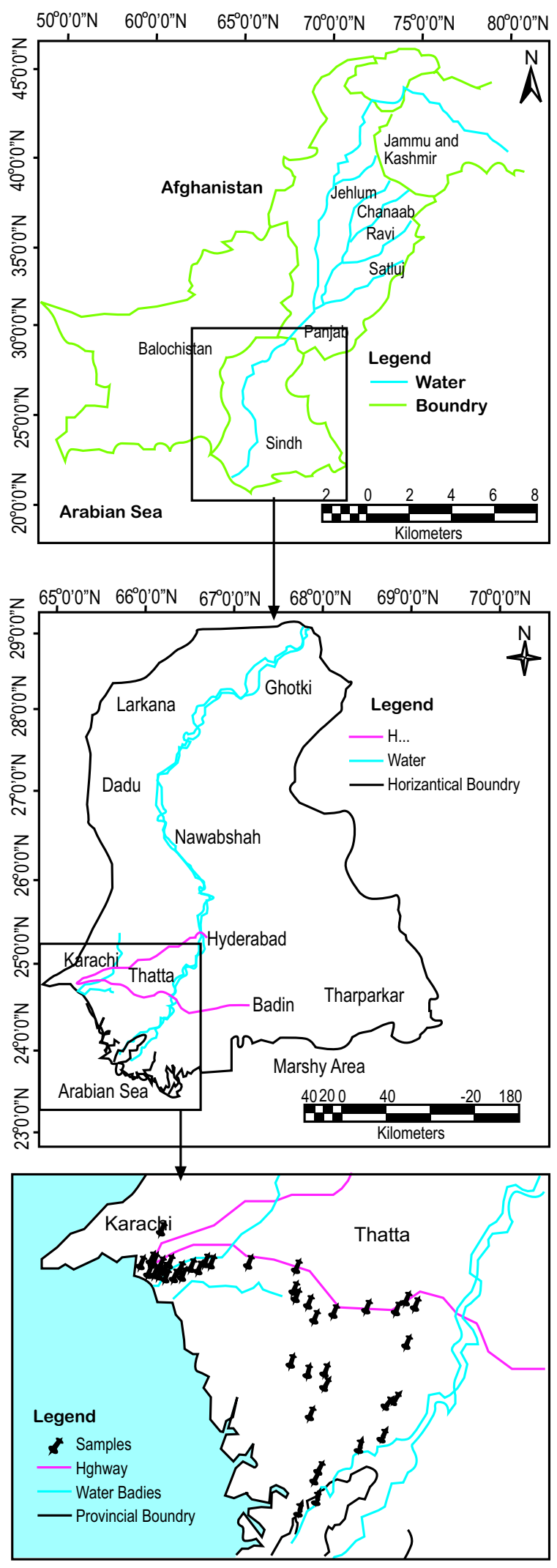

Fig. 1. Map showing the sampling locations in the present study. 
Samples were carefully collected to avoid any contamination which can deteriorate the sampled water quality; therefore, it was sampled from the well after the well was pumped long enough to ensure that temperature, $\mathrm{pH}$ and conductivity stabilize.

Field measurement was made for physical parameters. Multimeter, Sension $156 \mathrm{HACH}$, USA were used to check conductivity, dissolved oxygen (DO), $\mathrm{pH}$, total dissolved solids (TDS), salinity and turbidity at sampling sites (APHA, 2005). Chemical analysis for major ions was performed in the laboratory by standard methods (Mitra and Kebbekus, 2018). Total hardness, alkalinity, and chloride $\left(\mathrm{Cl}^{-}\right)$analysis were measured with the help of titrimetric method. Additionally, sulfate $\left(\mathrm{SO}_{4}^{-2}\right)$, nitrate $\mathrm{NO}_{3}^{-}$, and chemical oxygen demand (COD) calculated by performing spectrophotometry, while flame-photometry was performed to determine sodium (Na) and potassium (K). Minitab version (11.12) and SPSS (IBM SPSS 20) software were used for graphs and statistical analysis. Specific conductance methods (Laxen, 1977) were used to monitor the accuracy of analytical work that relies on tentatively determined and associations among specific conductance and ionic strength.

\section{Results and Discussion}

Geochemical evolution. Normalized charge balance index (NCBI) was calculated using the formula described by (Mor et al., 2009; Kumar et al., 2007):

$$
\mathrm{NCBI}=\frac{\sum \mathrm{TZ}^{-}-\sum \mathrm{TZ}^{+}}{\sum \mathrm{TZ} Z^{-}+\sum \mathrm{TZ}^{+}}
$$

The sum of total anions $\left(\sum \mathrm{TZ}^{-}\right)$and the sum of the total cations $\left(\sum \mathrm{TZ}^{+}\right)$in milliequivalent were analyzed in groundwater samples. Statistical analysis of the total cation and total anions in pre-monsoon and postmonsoon seasons are significantly correlated (Fig. 2). It has been revealed from the observations that most of the samples were in the range of $10 \%$ error (charge balance equation) and balance is in support of cations. Fig. 3 shows the relation between Hardness $(\mathrm{Ca}+\mathrm{Mg})$ and Alkalinity $\left(\mathrm{HCO}_{3}+\mathrm{CO}_{3}\right)$. Cations are in excess and alkalinity of the earth metals in aquafer of the study area is balanced by $\mathrm{Ca}+\mathrm{Mg}$ cations. Further, it can be seen that the overall equilibrium of charge is maintained with cations dominancy.

It is implicated that the contribution of ions other than measured ions is insignificant for the total charge balance
(Maharana et al., 2015). As shown in Fig. $3, \mathrm{Mg}^{+2}$ and $\mathrm{Ca}^{+2}$ ions were in excess while the alkalinity of the groundwater (hardness) was balanced by the alkaline earth metals in the aquifers of the coastal region of Sindh in both seasons. Most of the samples displayed a similar trend and are influenced by local geology of the area (Sajil et al., 2019; Chacha et al., 2018; Elmahdy and Mohamed, 2013). This is further demonstrated that most of the points fall near the aquiline. Fig. 4 reveals that most of the samples fall along the aquiline, signifying the balanced contribution towards the charge equilibrium.

In spite of the control of evaporation/crystallization process occurrence in the groundwater, the ion chemistry
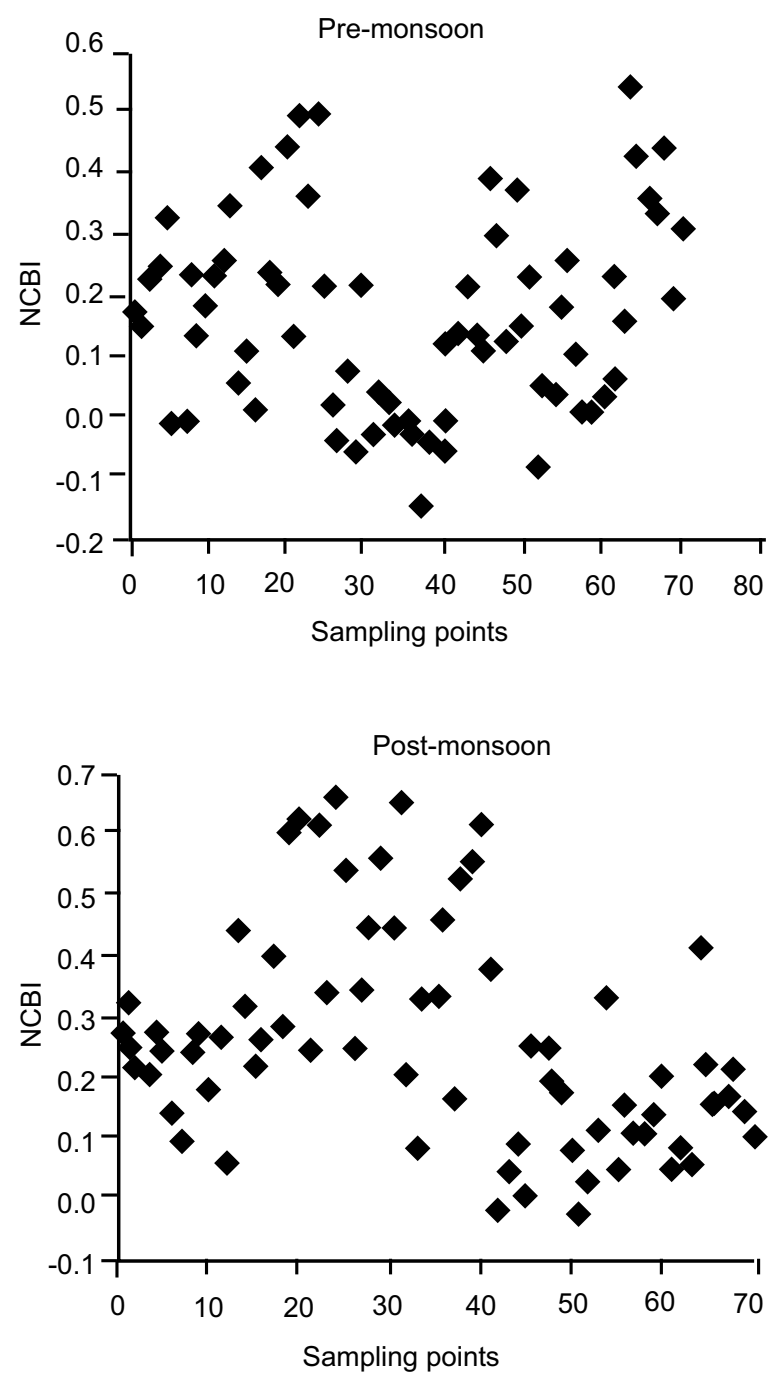

Fig. 2. Normalized charge balance index (NCBI) of the groundwater samples. 
was generally controlled by alkaline earth metals (Puntoriero et al., 2015). The same is being demonstrated by Gibb's plot (Fig. 5), which demonstrates the $40 \%$ variables fall in the rock control and $60 \%$ towards crystalline evaporation dominance and consequence from the weathering process of dolomite, gypsum and calcite rocks. Sodium is the leading cation in the groundwater and is governed by the alkaline earth metals $\left(\mathrm{Mg}^{+2}\right.$ and $\left.\mathrm{Ca}^{+2}\right)$.

It is apparent that groundwater with high TDS is due to Gaj formation which is more clay formation than Nari formation of Oligocene age (Rahman et al., 2018). The ion exchange reaction between rock and groundwater is high in Gaj formation due to mobile ions and
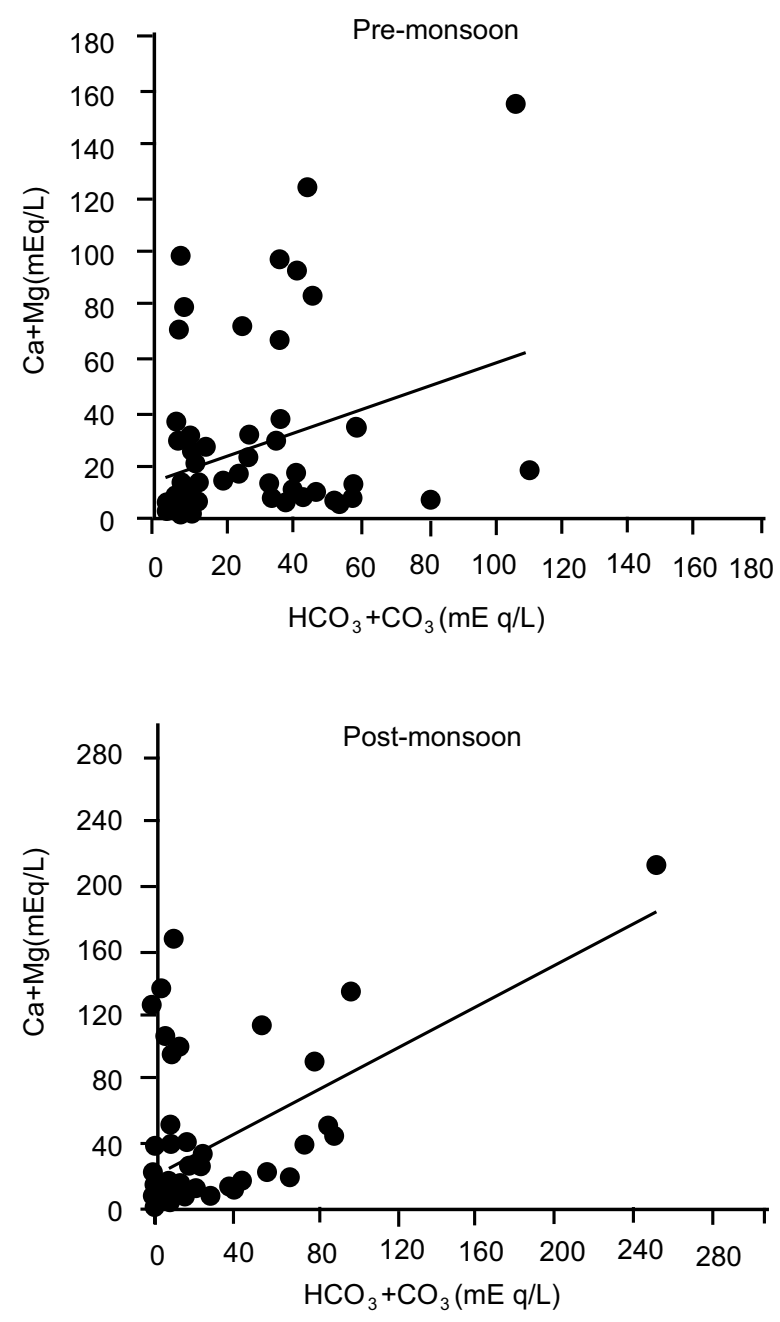

Fig. 3. Showing the relation between Hardness $(\mathrm{Ca}+\mathrm{Mg})$ and Alkalinity $\left(\mathrm{CO}_{3}+\mathrm{HCO}_{3}\right)$ during both seasons.
Hydrophiles such as sodium, potassium, and calcium. The Gibbs plot also represents a major contribution of rock because of recharge during monsoon lowers the ions concentration due to the increase in groundwater columns and dilution (Mondal et al., 2010).

The present study shows that the contribution of ions is predominantly by the rocks belonging to Miocene in age (Fig. 6). The hydrogeochemical evaluation in the current study area (Fig. 7) demonstrates that many of the groundwater samples drop in the rock governance area that results from the weathering of gypsum, dolomite and calcite rocks. Even though $\mathrm{Na}^{+}$is the most governing cation and groundwater chemistry is governed by $\mathrm{Mg}^{+2}$ and $\mathrm{Ca}^{+2}$ ions (Chang and Wang, 2010).
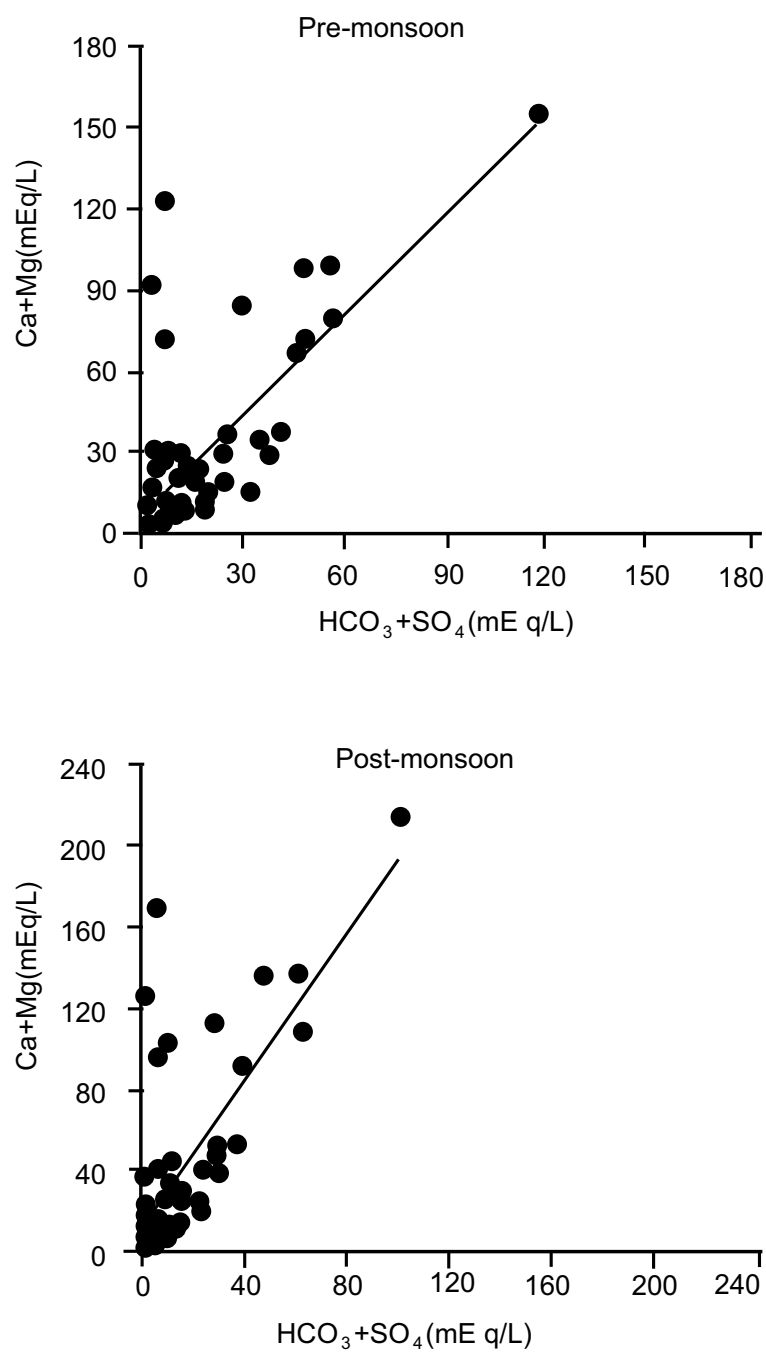

Fig. 4. Showing the relation between hardness $(\mathrm{Ca}+\mathrm{Mg})$ and acidic anion $\left(\mathrm{HCO}_{3}+\mathrm{SO}_{4}\right)$. 
It is obvious that alkali metal has control over alkaline earth metals while weak acidic anions were controlled by strong acidic anions (Essington, 2015). Both alkaline earth and alkali metal were controlled by the geochemistry of the aquifer in the study area.

Correlation analysis. Correlation analysis (bivariate method) was adopted to explain the extent of the relation between two hydro-chemical variables. The outcome of the correlation analysis was considered in the succeeding interpretation. A positive and negative correlation was observed among many variables. Standard normal distribution was assumed by correlation of the used parameters that must be analyzed for the
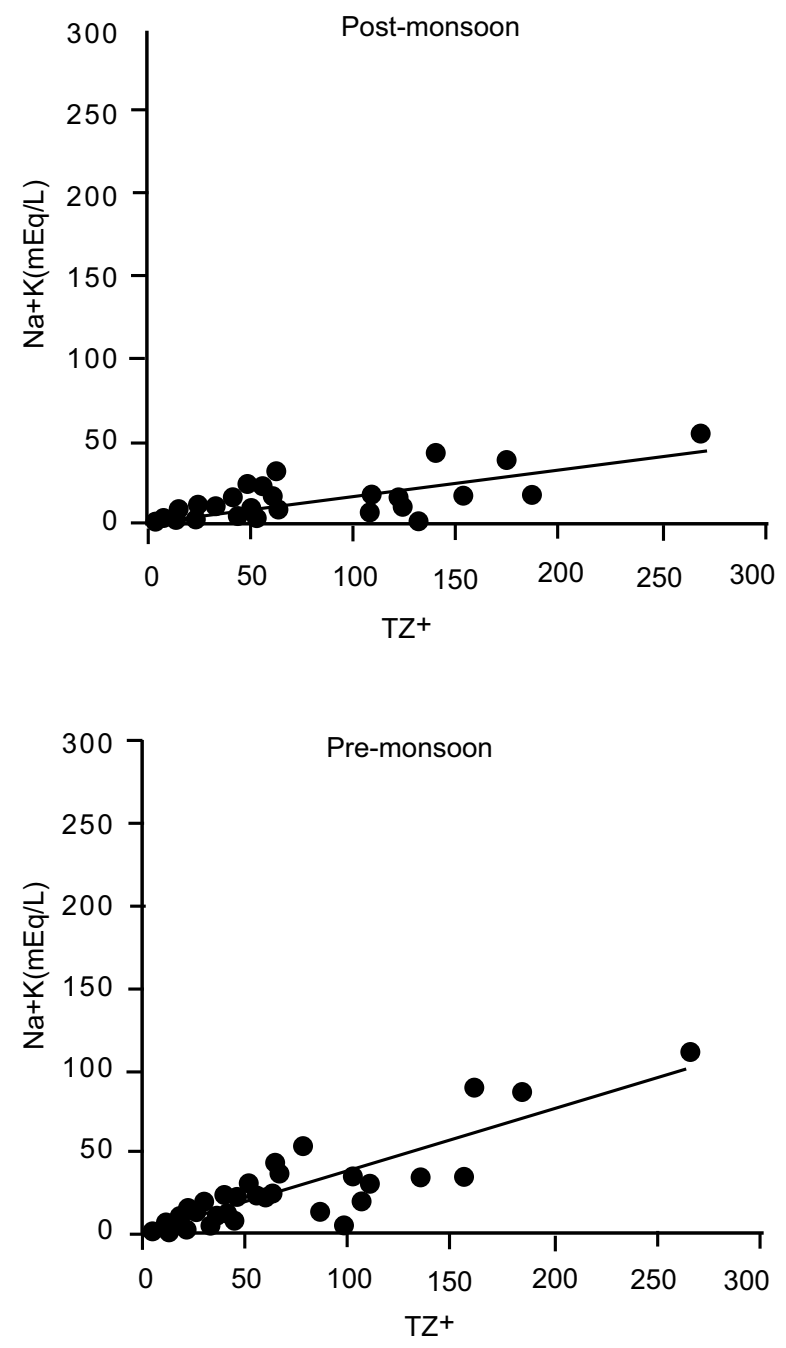

Fig. 5. Showing the relation between alkali metals $(\mathrm{K}+\mathrm{Na})$ and total cations $\left(\mathrm{TZ}^{+}\right)$during premonsoon and post-monsoon seasons. pre-established significance level (Vasanthavigar et al., 2010).

The correlation of all parameters during the pre-monsoon season is shown in Table 1. It is apparent in the table that $\mathrm{pH}$ has a positive correlation with dissolved oxygen and negatively correlated with potassium. Conductivity showed a positive correlation with TDS, Salinity, sodium, calcium, chloride, nitrate, and bicarbonate. Dissolved oxygen showed a negative correlation with potassium while positively correlated with carbonate. Sodium showed a positive correlation with magnesium, calcium, chloride and bicarbonate variables. Potassium was positively correlated with nitrate only. Calcium showed
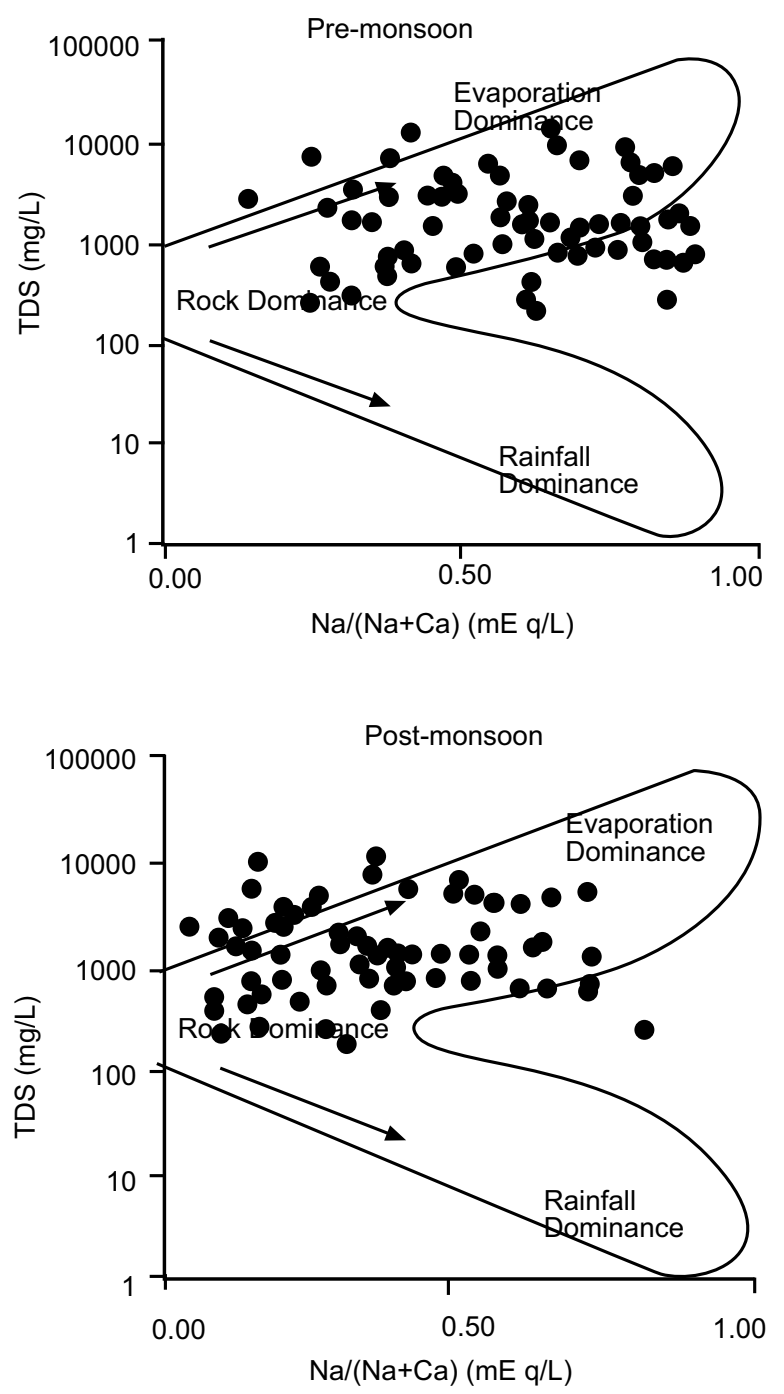

Fig. 6. Gibb's plot showing hydrogeochemical processes in groundwater. 
a negative correlation with fluoride whereas positively correlated with magnesium, chloride, sulphate and bicarbonate. Magnesium showed a positive correlation with sulfate, bicarbonate, and repeat. Chloride showed a positive correlation with sulfate, bicarbonate and nitrate.

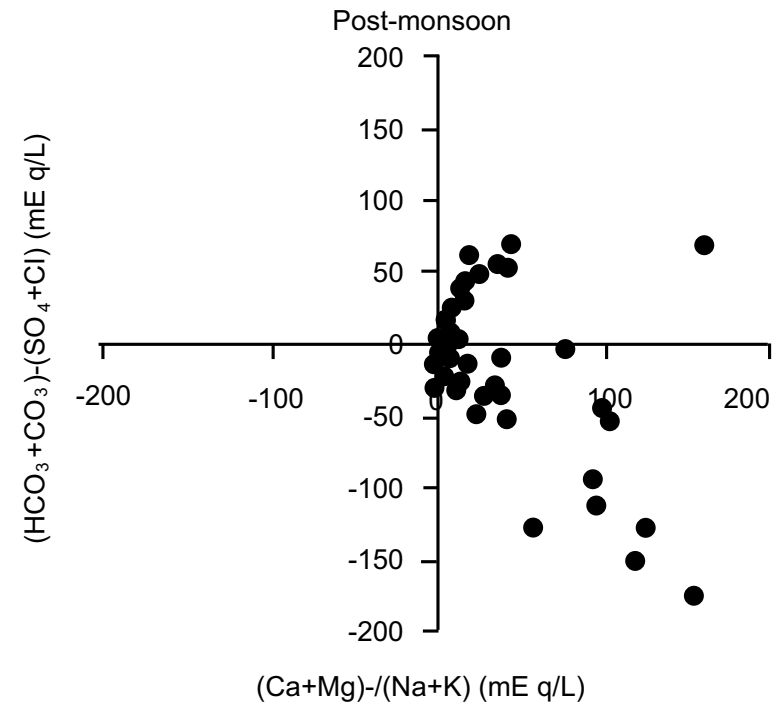

The correlation of all variables during post-monsoon presented in Table 2 . The $\mathrm{pH}$ negatively correlated with potassium and showed a positive correlation with dissolved oxygen. Conductivity was highly significantly correlated with TDS $(\mathrm{p}<0.001)$ and showed a strong positive correlation with TDS, salinity, sodium, calcium,

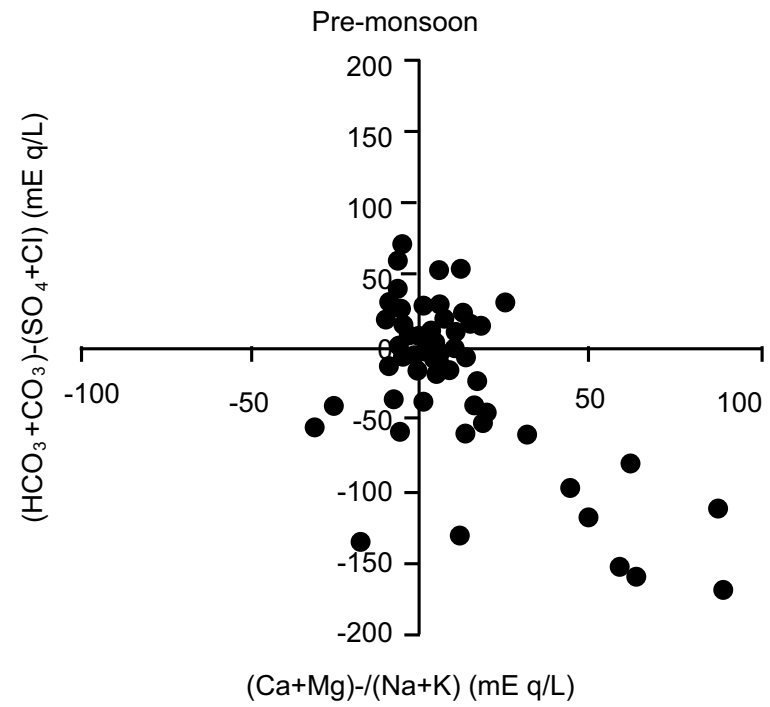

Fig. 7. Hydrogeochemical evaluation of ground-water of the study area.

Table 1. Correlation matrix of mean values of water samples during pre-monsoon season

\begin{tabular}{|c|c|c|c|c|c|c|c|c|c|c|c|c|c|c|c|}
\hline & $\mathrm{pH}$ & Con. & TDS & Salinity & DO & $\mathrm{Na}$ & K & $\mathrm{Ca}$ & $\mathrm{Mg}$ & $\mathrm{F}$ & $\mathrm{Cl}$ & $\mathrm{NO}_{3}$ & $\mathrm{HCO}_{3}$ & $\mathrm{CO}_{3}$ & $\mathrm{PO}_{4}$ \\
\hline Con. & -0.199 & & & & & & & & & & & & & & \\
\hline TDS & -0.190 & 0.995 & & & & & & & & & & & & & \\
\hline Salinity & -0.202 & 0.483 & 0.504 & & & & & & & & & & & & \\
\hline DO & 0.354 & -0.179 & -0.196 & -0.133 & & & & & & & & & & & \\
\hline $\mathrm{Na}$ & -0.064 & 0.759 & 0.764 & 0.458 & -0.086 & & & & & & & & & & \\
\hline $\mathrm{K}$ & -0.494 & 0.276 & 0.279 & 0.156 & -0.388 & 0.190 & & & & & & & & & \\
\hline $\mathrm{Ca}$ & -0.043 & 0.684 & 0.697 & 0.583 & -0.005 & 0.704 & 0.007 & & & & & & & & \\
\hline $\mathrm{Mg}$ & -0.032 & 0.722 & 0.735 & 0.609 & -0.053 & 0.731 & 0.080 & 0.940 & & & & & & & \\
\hline $\mathrm{F}$ & -0.167 & -0.251 & -0.253 & -0.234 & -0.254 & -0.231 & 0.018 & -0.387 & -0.311 & & & & & & \\
\hline $\mathrm{Cl}$ & -0.062 & 0.748 & 0.760 & 0.542 & 0.014 & 0.746 & 0.169 & 0.919 & 0.945 & -0.331 & & & & & \\
\hline $\mathrm{NO}_{3}$ & -0.227 & 0.396 & 0.417 & 0.238 & -0.164 & 0.293 & 0.391 & 0.193 & 0.281 & -0.124 & 0.360 & & & & \\
\hline $\mathrm{HCO}_{3}$ & 0.156 & 0.444 & 0.465 & 0.196 & -0.266 & 0.572 & -0.091 & 0.544 & 0.517 & -0.199 & 0.368 & -0.051 & & & \\
\hline $\mathrm{CO}_{3}$ & 0.254 & -0.001 & -0.011 & -0.121 & 0.436 & -0.006 & -0.055 & -0.054 & 0.017 & 0.004 & 0.067 & 0.201 & -0.176 & & \\
\hline $\mathrm{PO}_{4}$ & -0.067 & 0.176 & 0.148 & 0.044 & 0.243 & 0.094 & -0.067 & 0.112 & 0.067 & -0.052 & 0.066 & -0.079 & -0.126 & 0.198 & \\
\hline $\mathrm{SO}_{4}$ & -0.274 & 0.321 & 0.321 & 0.670 & 0.016 & 0.340 & 0.054 & 0.577 & 0.536 & -0.217 & 0.435 & 0.064 & 0.107 & -0.186 & 0.151 \\
\hline
\end{tabular}

Here , Con. $=$ Conductivity; TDS $=$ Total Dissolve Solids; $\mathrm{DO}=$ Dissolve Oxygen $; \mathrm{Na}=$ Sodium; $\mathrm{K}=$ Potassium; $\mathrm{Ca}=\mathrm{Calcium}$; $\mathrm{Mg}=$ Magnesium; $\mathrm{F}=$ Fluoride $; \mathrm{Cl}=$ Chloride $\mathrm{NO}_{3}=$ Nitrate $\mathrm{HCO}_{3}=$ Bicarbonate $\mathrm{CO}_{3}=$ Carbonate $\mathrm{PO}_{4}=\mathrm{Phosphate}$ $\mathrm{SO}_{4}=$ Sulfate; Values greater than 0.250 and less than $0.324(\mathrm{p}<0.05)$ significant; Values greater than 0.324 and less than 0.407 $(p<0.01)$ more significant; Values greater than $0.407(p<0.001)$ highly significant; Significance level for degree of freedom 68 was checked by using $\mathrm{r}$ table in sequence order; Bold face numbers indicate statistically significant correlation coefficient. 
Table 2. Correlation matrix of mean values of water samples during post-monsoon season

\begin{tabular}{|c|c|c|c|c|c|c|c|c|c|c|c|c|c|c|c|}
\hline & $\mathrm{pH}$ & Con. & TDS & Salinity & DO & $\mathrm{Na}$ & K & $\mathrm{Ca}$ & $\mathrm{Mg}$ & $\mathrm{F}$ & $\mathrm{Cl}$ & $\mathrm{NO}_{3}$ & $\mathrm{HCO}_{3}$ & $\mathrm{CO}_{3}$ & $\mathrm{PO}_{4}$ \\
\hline Con. & -0.169 & & & & & & & & & & & & & & \\
\hline TDS & -0.172 & 0.996 & & & & & & & & & & & & & \\
\hline Salinity & -0.191 & 0.446 & 0.496 & & & & & & & & & & & & \\
\hline DO & 0.393 & -0.242 & -0.263 & -0.143 & & & & & & & & & & & \\
\hline $\mathrm{Na}$ & -0.070 & 0.773 & 0.789 & 0.478 & -0.194 & & & & & & & & & & \\
\hline K & -0.494 & 0.271 & 0.279 & 0.146 & -0.408 & 0.214 & & & & & & & & & \\
\hline $\mathrm{Ca}$ & -0.017 & 0.682 & 0.706 & 0.585 & -0.052 & 0.700 & 0.006 & & & & & & & & \\
\hline $\mathrm{Mg}$ & -0.006 & 0.717 & 0.742 & 0.615 & -0.100 & 0.715 & 0.081 & 0.944 & & & & & & & \\
\hline F & -0.219 & -0.326 & -0.341 & -0.292 & -0.132 & -0.312 & -0.007 & -0.506 & -0.427 & & & & & & \\
\hline $\mathrm{Cl}$ & -0.028 & 0.742 & 0.762 & 0.537 & -0.054 & 0.748 & 0.162 & 0.922 & 0.948 & -0.432 & & & & & \\
\hline $\mathrm{NO}_{3}$ & -0.202 & 0.405 & 0.426 & 0.234 & -0.189 & 0.324 & 0.376 & 0.191 & 0.262 & -0.147 & 0.346 & & & & \\
\hline $\mathrm{HCO}_{3}$ & 0.151 & 0.460 & 0.477 & 0.205 & -0.303 & 0.586 & -0.082 & 0.553 & 0.528 & -0.272 & 0.397 & -0.044 & & & \\
\hline $\mathrm{CO}_{3}$ & 0.274 & 0.028 & 0.011 & -0.119 & 0.412 & -0.008 & -0.052 & -0.048 & 0.010 & 0.054 & 0.070 & 0.219 & -0.181 & & \\
\hline $\mathrm{PO}_{4}$ & -0.050 & 0.207 & 0.179 & 0.084 & 0.212 & 0.102 & -0.059 & 0.118 & 0.081 & -0.048 & 0.071 & -0.086 & -0.127 & 0.228 & \\
\hline $\mathrm{SO}_{4}$ & -0.245 & 0.344 & 0.364 & 0.715 & -0.059 & 0.374 & 0.076 & 0.522 & 0.530 & -0.264 & 0.367 & 0.067 & 0.136 & -0.180 & 0.188 \\
\hline
\end{tabular}

Here, Con. $=$ Conductivity; $\mathrm{TDS}=$ Total Dissolve Solids; $\mathrm{DO}=$ Dissolve Oxygen; $\mathrm{Na}=$ Sodium; $\mathrm{K}=$ Potassium; $\mathrm{Ca}=\mathrm{Calcium}$; $\mathrm{Mg}=$ Magnesium; $\mathrm{F}=$ Fluoride $; \mathrm{Cl}=$ Chloride; $\mathrm{NO}_{3}=$ Nitrate $\mathrm{HCO}_{3}=$ Bicarbonate; $\mathrm{CO}_{3}=$ Carbonate; $\mathrm{PO}_{4}=\mathrm{Phosphate}$ $\mathrm{SO}_{4}=$ Sulfate; Values greater than 0.250 and less than $0.324(\mathrm{p}<0.05)$ significant; Values greater than 0.324 and less than 0.407 $(\mathrm{p}<0.01)$ more significant; Values greater than $0.407(\mathrm{p}<0.001)$ highly significant; Significance level for degree of freedom 68 was checked by using $r$ table in sequence order; Bold face numbers indicate statistically significant correlation coefficient.

magnesium, chloride, nitrate and bicarbonate. TDS showed a weak negative correlation with fluoride and positively correlated with salinity, sodium, calcium, magnesium, chloride, nitrate sulfate and bicarbonate. Salinity showed a positive correlation with sodium, calcium, magnesium, chloride, and sulfate. Dissolved Oxygen was negatively correlated with potassium while positively correlated with carbonate. Sodium showed a positive correlation with bicarbonate, sulfate, chloride, magnesium, and calcium. Calcium showed a negative correlation with fluoride while positively correlated with magnesium, chloride, bicarbonate, and sulfate. Magnesium was negatively correlated with fluoride and showed a positive correlation with chloride, sulfate and bicarbonate. Therefore, it can be assumed that the correlation studies of the groundwater quality parameters have great importance and the non-significant correlation between parameters, and they are independent to each other.

\section{Conclusion}

The present study revealed that the ion exchange reaction between rock and groundwater is high in Gaj formation due to mobile ions and hydrophiles such as sodium, potassium, calcium, magnesium, and chloride and characterizes the nature of groundwater in the study area. Precipitation directly impacts the groundwater quality and infiltration takes place at a high level during the post-monsoon period. During water flow through residual rocks formations, that affects groundwater quality by changing the concentration of ions. The major changes in the groundwater of the study area are found naturally during both seasons.

Conflict of Interest. The authors declare no conflict of interest.

\section{References}

Alamgir, A., Khan, M.A., Schilling, J., Shaukat, S.S., Shahab, S. 2016. Assessment of groundwater quality in the coastal area of Sindh province, Pakistan. Environmental Monitoring and Assessment, 78: 1-13.

APHA, 2005. Standard Methods for the Examination of Water and Wastewater, $21^{\text {st }}$ Edition, Washington, DC, USA.

Bashir, E., Huda, S.N.U., Naseem, S., Hamza, S., Kaleem, M. 2017. Geochemistry and quality parameters of dug and tube well water of Khipro, district Sanghar, Sindh, Pakistan. Applied Water Science, 7: 1645-1655. 
Chacha, N., Njau, K.N., Lugomela, G.V., Muzuka, A.N. 2018. Hydrogeochemical characteristics and spatial distribution of groundwater quality in arusha well fields, northern Tanzania. Applied Water Science, 8: $1-23$.

Chang, J., Wang, G. 2010. Major ions chemistry of groundwater in the arid region of zhangye basin, northwestern China. Environmental Earth Sciences, 61: 539-547.

Daud, M.K., Nafees, M., Ali, S., Rizwan, M., Bajwa, R.A., Shakoor, M.B., Arshad, M.U., Chatha, S.A.S., Deeba, F., Murad, W., Malook, I. 2017. Drinking water quality status and contamination in Pakistan. BioMed Research International, 2017: 1-18.

Elmahdy, S.I., Mohamed, M.M. 2013. Influence of geological structures on groundwater accumulation and groundwater salinity in musandam peninsula, UAE and Oman. Geocarto International, 28: 453472.

Essington, M.E. 2015. Soil and Water Chemistry: An Integrative Approach. $2^{\text {nd }}$ Edition, pp. 311-320; CRC Press, London, UK. ISBN 9781466573154.

Husain, V., Naseem, S., Khan, A., Bhattacharya, P., Arain, G.M. 2012. Natural arsenic in groundwater of Indus delta in the province of Sindh, Pakistan. understanding the geological and medical interface of arsenic. London: Taylor and Francis, 6: 31-32.

Khuhawar, M.Y., Brohi, R.O.Z., Jahangir, T.M., Lanjwani, M.F. 2018. Water quality assessment of ramser site, indus delta, Sindh, Pakistan. Environmental Monitoring and Assessment, 492: 2-11.

Kumar, M., Kumari, K., Ramanathan, A.L., Saxena, R. 2007. A comparative evaluation of groundwater suitability for irrigation and drinking purposes in two intensively cultivated districts of Punjab, India. Environmental Geology, 53: 553-574.

Laxen, D.P.H. 1977. A specific conductance method for quality control in water analysis. Water Research, 11: 91-94.

Maharana, C., Gautam, S.K., Singh, A.K., Tripathi, J.K. 2015. Major ion chemistry of the Son river, India: weathering processes, dissolved fluxes and water quality assessment. Journal of Earth System Science, 124: 1293-1309.

Malkani, M.S. 2010. New Pakisaurus (Pakisauridae, Titanosauria, Sauropoda) Remains, and Cretaceous Tertiary (KT) Boundary from Pakistan. Sindh University Research Journal (Science Series), 42: 39-64.

Malott, S., O'Carroll, D.M., Robinson, C.E. 2016.
Dynamic groundwater flows and geochemistry in a Sandy nearshore aquifer over a wave event. Water Resources Research, 52: 5248-5264.

Mastoi, G.M., Shah, S.G.S., Khuhawar, M.Y. 2008. Assessment of water quality of Manchar lake in Sindh (Pakistan). Environmental Monitoring and Assessment, 141: 287-296.

Memon, M., Soomro, M.S., Akhtar, M.S., Memon, K.S. 2011. Drinking water quality assessment in southern sindh (Pakistan). Environmental Monitoring and Assessment, 177: 39-50.

Mitra, S., Kebbekus, B.B. 2018. Environmental Chemical Analysis. $2^{\text {nd }}$ Edition, pp. 200-306; CRC press, Providence, Rhode Island, USA.

Mondal, N.C., Singh, V.P., Singh, V.S., Saxena, V.K. 2010. Determining the interaction between groundwater and saline water through groundwater major ions chemistry. Journal of Hydrology, 388: 100111.

Mor, S., Singh, S., Yadav, P., Rani, V., Rani, P., Sheoran, M., Singh, G., Ravindra, K. 2009. Appraisal of Salinity and fluoride in a semi-arid region of India using statistical and multivariate techniques. Environmental Geochemistry and Health, 643: 1-25.

Puntoriero, M.L., Cirelli, A.F., Volpedo, A.V. 2015. Geochemical mechanisms controlling the chemical composition of groundwater and surface water in the southwest of the pampean plain (Argentina). Journal of Geochemical Exploration, 150: 64-72.

Qureshi, A.S., McCornick, P.G., Qadir, M., Aslam, Z. 2008. Managing salinity and waterlogging in the Indus basin of Pakistan. Agricultural Water Management, 95: 1-10.

Qureshi, A.S., McCornick, P.G., Sarwar, A., Sharma, B.R. 2010. Challenges and prospects of sustainable groundwater management in the Indus basin, Pakistan. Water Resources Management, 24: 15511569.

Qureshi, S. 2010. The fast growing megacity Karachi as a frontier of environmental challenges: urbanization and contemporary urbanism issues. Journal of Geography and Regional Planning, 3: 306-321.

Rahman, M.M., Islam, M.A., Bodrud-Doza, M., Muhib, M.I., Zahid, A., Shammi, M., Tareq, S.M., Kurasaki, M. 2018. Spatio-temporal assessment of groundwater quality and human health risk: A case study in gopalganj, Bangladesh. Exposure and Health, 10: $167-188$. 
Rasul, G., Mahmood, A., Sadiq, A., Khan, S.I. 2012. Vulnerability of the Indus delta to climate change in Pakistan. Pakistan Journal of Meteorology, 16: 89-107.

Rubab, G., Naseem, S., Khan, A., Husain, V., Arain, G.M. 2014. Distribution and sources of arsenic contaminated groundwater in parts of Thatta district, Sindh. Journal of Himalayan Earth Sciences, 47: 175-183.

Sajil, K.P., Mohanan, A.A., Ekanthalu, V.S. 2019. Hydrogeochemical analysis of groundwater in Thanjavur district, Tamil nadu; influences of geological settings and land use pattern. Geology, Ecology and Landscapes, 4: 1-12.

Steenbergen, F., Basharat, M., Lashari, B. 2015. Key challenges and opportunities for conjunctive management of surface and groundwater in megairrigation systems: lower Indus, Pakistan. Resources, 4: 831-856.

Vasanthavigar, M., Srinivasamoorthy, K., Vijayaragavan,
K., Ganthi, R.R., Chidambaram, S., Anandhan, P., Manivannan, R., Vasudevan, S. 2010. Application of water quality index for groundwater quality assessment: Thirumanimuttar sub-basin, Tamilnadu, India. Environmental Monitoring and Assessment, 171: 595-609.

Yu, W., Yang, Y.C., Savitsky, A., Alford, D., Brown, C., Wescoat, J., Debowicz, D., Robinson, S. 2013. The Indus basin of Pakistan: The impacts of climate risks on water and agriculture. The World Bank Washington, DC, USA: World Bank ISBN: 978-08213-9874-6.

Zeb, S., Iqbal, M.Z., Shafiq, M., Athar, M. 2017. The effect of particulate matter on stomatal clogging in certain roadside plants of Karachi, Pakistan. Scientia, 17: 98-104.

Zubair, A., Hussain, A., Farooq, M.A., Abbasi, H.N. 2010. Impact of storm water on groundwater quality below retention/detention basins. Environmental Monitoring and Assessment, 162: 427-437. 